\title{
The effectiveness of a psycho-educational nursing intervention on illness perception, knowledge and expressed emotion of caregivers of patients with first episode psychosis
}

\author{
Hanaa Mohamed Abo Shereda*1, Safaa Ibrahim Shattla ${ }^{1}$, Hemat Mostafa Amer ${ }^{2}$, Zeinab Abdel Aziz Kasemy ${ }^{3}$ \\ ${ }^{1}$ Psychiatric and Mental Health Nursing Department, Faculty of Nursing, Menoufia University, Egypt \\ ${ }^{2}$ Family and Community Health Nursing Department, Faculty of Nursing, Menoufia University, Egypt \\ ${ }^{3}$ Public health and Community Medicine, Faculty of Medicine, Menoufia University, Egypt
}

Received: November 12, 2018

DOI: $10.5430 /$ jnep.v9n8p118
Accepted: March 10, $2019 \quad$ Online Published: April 18, 2019

URL: https://doi.org/10.5430/jnep.v9n8p118

\begin{abstract}
Background: Psycho educational nursing intervention to families of patients with first-episode psychosis is highly recommended to assist families to overcome feelings of stress, guilt, stigma, loss of control and to promote recovery of patients. The aim of the study was to evaluate the effect of psych educational nursing intervention on illness perception, level of knowledge and level of expressed emotion of caregivers of patients with first episode psychosis.

Methods: Research design: a quasi-experimental research design (one group pre-posttest) was used to achieve the aim of the study. The study was conducted at three psychiatric and mental health governmental outpatient clinics. A convenience sample of 50 caregivers was used. Data was collected using socio demographic data questionnaire, family questionnaire, knowledge questionnaire, and illness perception questionnaire.

Results: There were clinically significant improvement among the caregivers' level of knowledge and illness perception at post test of psycho educational nursing intervention than before intervention, while level of expressed emotion was improved post the psycho educational nursing intervention but without obvious significant difference.

Conclusions \& Recommendation: Psycho educational nursing intervention was effective in improving caregivers' level of knowledge, illness perception and expressed emotion. The study recommended to urgently utilize psycho educational nursing intervention to all caregivers of patient with first episode psychosis in all psychiatric hospitals.
\end{abstract}

Key Words: First episode psychosis, Caregivers, Psycho educational nursing intervention, Expressed emotions

\section{INTRODUCTION}

Psychosis is a syndrome that can occur with many other diseases. It consists of any severe form of mental disorder in which there is poor or highly distorted contact with reality. ${ }^{[1]}$ Psychosis primarily involves changes in thinking, percep- tion and emotions. Psychosis has many causes including substance abuse, exposure to severe stress, genetic medical conditions or diseases, and mood disorders. ${ }^{[2]}$ Families have central positions in care of patients and psychosocial rehabilitation. Caregivers both affect and are affected by

*Correspondence: Hanaa Mohamed Abo Shereda; Email: cats.girls77@yahoo.com; Address: Psychiatric and Mental Health Nursing Department, Faculty of Nursing, Menoufia University, Egypt. 
a mentally ill patient through a dynamic process affecting patterns of communication, interactional styles, family roles, and responsibilities in order to adapt with the physical and psychological demands for managing the illness. ${ }^{[3]}$ Family caregivers of individuals suffering from first episode psychosis have a higher risk of distress and face a number of issues, such as shock, grief, poor understanding of illness and the psychiatric system, compared to family caregivers of individuals with a prolonged course of illness. Unfortunately, the stress experienced by caregivers during the first episode can sometimes hamper recovery and even lead to a relapse. ${ }^{[4]}$

Research evidence has demonstrated the clinical efficacy of a few approaches to family intervention, especially psychoeducation and behavioral or crisis management programs, in reducing patients' relapses from their psychotic disorders. ${ }^{[5]}$ Mental healthcare or psychiatric treatment guide-lines in both the US and UK suggest that family-based (caregivers) intervention can be an integral of a community-based rehabilitation program to produce significant positive patients' outcomes in early psychosis whenever their family caregivers can improve in coping with their caregiving role and psychosocial functioning especially with the advent of deinstitualization where mentally ill patients are greatly stayed in the community and depend on their families in their care. ${ }^{[6]}$

Caregivers' role in the treatment of mentally ill patients has become important due to many reasons. For example, factors in family members' behavior and attitude towards patients such as criticality, hostility, and over-involvement which predict relapse in individuals with prolonged psychosis and first episode psychosis. ${ }^{[7]}$ Moreover, providing care to a person with severe mental illness can adversely affect the mental health and well-being of family caregivers. ${ }^{[8,9]}$

Nurses play an important role in providing a psychoeducational nursing intervention that may empower caregivers to identify their own problems and needs, further more to minimize professional input. ${ }^{[10,11]}$

\subsection{Significance of the study}

Caregivers are often an important source of support and facilitation for mentally ill patients' treatment and rehabilitation. Because little attention is given to the family caregivers' health and well-being. There is a growing understanding among mental health professional's especially nursing staff about the need to help the family caregivers along with the patients. Consequently, family interventions are now strongly recommended in many standards. ${ }^{[12-14]}$

While there is no practice guideline available in Egypt. A psycho-educational program for family caregivers and their patients with first episode of psychotic disorders is highly

Published by Sciedu Press recommended. It can enable both patients and caregivers to better engage with the patient care through enhancing their knowledge and insight into the illness, medication adherence and coping with their psychotic symptoms, thus improving prognosis. ${ }^{[15,16]}$

\subsection{Aim of the study}

The aim of the study was to evaluate the effect of psychoeducational nursing intervention on illness perception, knowledge and expressed emotion of caregivers of patients with first episode psychosis.

\subsection{Research hypothesis}

H1: Caregivers who attend the psycho educational nursing intervention will have an accepted level of expressed emotion than before intervention. H2: Caregivers who attend the psycho educational nursing intervention will have positive illness perception than before intervention. H3: Caregivers who attend the psycho educational nursing intervention will have an increased level of knowledge about mental illness than before intervention

\section{Methods}

\subsection{Research design}

A quasi-experimental research design (pre-posttest) was used to achieve the aim of the study.

\subsection{Setting}

The study was conducted in three psychiatric and mental health governmental hospitals (out patients clinics) which include; Mitkhalf mental health hospital at Menoufia, Egypt, Mental health hospital in Tanta and Psychiatric and Mental health department in Tanta university hospital, Egypt. These settings are the main governmental hospitals in Delta Region and known to have the highest number of patient.

\subsection{Subject}

Convenience sample of 50 caregivers were recruited according the following inclusion criteria:

(1) Caregivers for patients with a first episode psychosis who are living with or directly involved in the care of patients.

(2) Ready and accepted to participate in the study.

The exclusion criteria were as follows:

(1) Care givers with psychiatric illness.

(2) Care givers with hearing problems.

(3) Care givers of patients with substance abuse. 


\subsection{Instruments}

\section{Socio-demographic data sheet}

Socio-demographic data sheet was developed by the researcher to collect the demographic details of the caregivers and patients. Information collected included age, gender, education, marital status, family income, occupation, duration of illness, duration of care giving and caregivers' relationship with patients and degree of relativeness and if care givers have psychiatric illness or not?

\section{Knowledge questionnaire (KQ)}

This tool was developed by Birchwood, Smith and Cochrane ${ }^{[17]}$ to measure knowledge about psychosis. The questionnaire was modified to make it more suitable to caregivers. A self-report instrument, it includes 23 questions divided into six specific areas of knowledge with regard to psychosis as risk factors (six questions); signs and symptoms (three questions); hospital treatment (two questions); medication treatment (four questions); caregiver support (five questions); and recovery (three questions). Some questions having just one correct answer, while other questions have many correct answers. When calculating scores of this questionnaire, score of (1) was given for each correct answer and 0 for each incorrect answer.

The maximum score achievable was 84 (higher than the originally cited 38).

\section{Family questionnaire (FQ)}

The FQ originally developed by Wiedemann, Rayki, Feinstein \& Hahlweg ${ }^{[18]}$ modified by Koutra et al. ${ }^{[19]}$ It was used to measure EE in caregivers of persons with various mental disorders. It consists of 20 items in which 10 items measures criticism (CC) and the remaining 10 items for emotional over-involvement (EOI). The scoring ranges from 1 as "never/rarely" to 4 as "very often" and a higher total score indicates higher EE. The authors provide a cut-off point of 23 for $\mathrm{CC}$ as an indication of high $\mathrm{CC}$, and 27 for high EOI.

VI. Illness perceptions questionnaire for Schizophreniarelatives' version (IPQS-R)

This tool was developed by Lobban, Barrowclough \& Jones. ${ }^{[20]}$ It used to measure relatives' beliefs about the mental disorder. The scale was divided into the following subscales: cause (personal ideas about the cause of the disorder), timeline acute/chronic and timeline cyclical (perception of the pattern and duration of the disorder), consequences for both patients and relative (the expected effects and outcome of the disorder), personal control-patient and personal control-relative (control over the disorder), personal blamepatient and personal blame relative(blame toward the patient or self-blame about the disorder). Treatment control/cure (usefulness of treatment), illness coherence (a coherent un- derstanding of the disorder) and emotional representation (negative emotions about the disorder including sense of fear, frustration, anger, loss, worry). The items are rated from 1 'strongly disagree' to 5 'strongly agree'.

Validity: The validity of the instruments was ascertained by a group of subject areas experts, medical and nursing staff who reviewed the instruments for content validity. They were asked also to judge the items for completeness, length, wording, relevance and clarity. Suggestions were incorporated into the instruments.

Reliability: Test-retest reliability was applied by the researchers for testing the internal consistency of the instruments. It is the administration of the same instruments to the same participants under similar conditions on two or more occasions. Scores from repeated testing were compared. All tools were strongly reliable. Family questionnaire has good internal consistency (value ranging from 0.78 to 0.80 for emotional over-involvement (EOI) and from 0.91 to 0.92 for criticism (CC). The internal consistency for Illness Perceptions Questionnaire for Schizophrenia-Relatives' version (IPQS-R) ranging from 0.82 for (Emotional representation) to 0.91 for (Negative consequences). The internal consistency of knowledge questionnaire is good (value ranging from 0.86 to 0.93 )

\subsection{Ethical considerations}

An official permission was granted up on a letter issued from the faculty of Nursing, Menoufia University and after research study aim, content and procedure were discussed with the directors of mental health hospitals before data collection procedure. The researchers met with the studied caregivers and explained the nature and purpose of the study, assumed them about confidentiality, anonymity and finally informed that they have the right to withdraw from the study at any time without giving any reason. After full explanation of the aim of the study, verbal consent was taken from all the participants before participation in the study.

\subsection{Pilot study}

A Piloting was conducted on 10 care givers of patients with first episode psychosis to test the applicability of the instruments and to estimate the time needed for data collection. On the basis of the piloting results the researchers determined the feasibility of data collection procedures, developed an interview schedule. The results of the piloting helped in refining the interview questionnaire.

\subsection{Data collection}

Data collection for this study was carried out in the period from the middle of June 2017 to the end of July 2018. The 
researchers collected the data during the morning from 10 am to $12 \mathrm{pm}$, two days/week.

\subsection{The intervention}

The current study was carried out in four phases: pre assessment phase assessment phase, implementation phase and evaluation phase.

Pre assessment phase: An extensive literature related to the study area was done including electronic dissertation, available books, articles, doctoral dissertation, research and peer interaction, and idea from external sources and periodicals. A review of literature to formulate knowledge base relevant to the study area was also done.

Assessment phase: A comfortable, private place was chosen for the interviewers. Orientation was done about the purpose of the study and content of the study. Each caregiver was individually interviewed where pre assessment was done using structured interviewing questionnaire, knowledge questionnaire, illness perception questionnaire and expressed emotion scale.

Implementation Phase: The Psycho educational nursing intervention was designed by the researchers and validated by a group of field expertise. The study group were divided into (5) groups every group ranged from (8 to 12) patients, every group attended (6) psycho educational nursing intervention session within two days/week from $10 \mathrm{am}$ to $12 \mathrm{pm}$. The intervention consisted of 6 sessions. Each session lasted for one hour and has a set of specific objective. The nursing intervention was utilized several teaching methods such as: brain storming, lectures, discussion, providing examples. Data show, videos, role play, pictures and evidence based booklets. Participants were invited to raise questions and make comments as they saw fit. A particular emphasis was placed on dispelling common myths. At the end of each session summary, feedback and further clarification were done for the vague items.

The topics covered in the presentation are mentioned in Table 1.

Table 1. The Psycho educational nursing intervention topics

\begin{tabular}{|l|l|}
\hline $1^{\text {st }}$ Week & - Introduction about mental illness diseases and mental illness services. \\
\hline $2^{\text {nd }}$ week & $\begin{array}{l}\text { - Identification of caregivers' current knowledge and understanding of psychosis. } \\
\text { - Explanation of signs and symptoms of psychiatric illness. }\end{array}$ \\
\hline $3^{\text {rd }}$ Week & $\begin{array}{l}\text { - Pharmacological management of psychiatric illness including (the action of medication- dosing-precautions } \\
\text { for medication - side effects - management of side effects). }\end{array}$ \\
\hline $4^{\text {th }}$ week & - How to communicate with psychiatric patient. \\
\hline $5^{\text {th }}$ week & - Psychological management of psychiatric illness (importance - types available). \\
\hline $6^{\text {th }}$ week & $\begin{array}{l}\text { - Strategies for relapse preventions including (signs and symptoms of relapse prevention, causes of relapse- } \\
\text { management of relapse). }\end{array}$ \\
\hline
\end{tabular}

The evaluating phase: During this phase, the participants were encouraged to ask any questions or demand clarifications they needed and the post-test was given to them using the same tools used in the pre test.

\subsection{Statistical data analysis}

Results were statistically analyzed by SPSS version 22 (SPSS Inc., Chikago, IL, USA). Wilcoxon and Mann-Whitney tests were used for non-parametric data. Chi-Squared $\left(\chi^{2}\right)$ tests were used for qualitative variables. $p$ value $<.05$ is considered significant.

\section{RESUlTS}

Table 2 shows that, the studied sample consisted of 50 caregivers of patients with first episode psychosis aged from 19 to 70 with a mean age $39.76 \pm 12.50,60 \%$ were male, $80 \%$ of them were from rural areas., not working and were married.

Published by Sciedu Press
$66 \%$ of the relative of patient with first episode psychosis had low education and the income of $62 \%$ of the patients was not enough. $34 \%$ of the caregivers of the patients were their brothers or sisters.

Figure 1 shows that, there was a statistically significant difference between the level of knowledge of the studied group at pre and post the psycho educational nursing intervention at $p<.001$.

Figure 2 displays that, there was no statistically significant difference between the levels of total expressed emotions of the studied group at pre and post the psycho educational nursing intervention $p<.001$.

Table 3 shows that, there were statistically significant differences among the illness perception subscale variables as perceived by the caregivers of patients with first episode 
psychosis at pre and post the psych educational nursing intervention at $p<.001$.

Table 2. General characteristics of the studied group

\begin{tabular}{|c|c|c|}
\hline General characteristics & \multicolumn{2}{|c|}{ Study group $(n=50)$} \\
\hline Mean \pm SD & \multicolumn{2}{|c|}{$39.76 \pm 12.50$} \\
\hline \multirow[t]{2}{*}{ Range } & \multicolumn{2}{|c|}{$19.0-70.0$} \\
\hline & No & $\%$ \\
\hline \multicolumn{3}{|l|}{ Sex } \\
\hline Male & 30 & 60.0 \\
\hline Female & 20 & 40.0 \\
\hline \multicolumn{3}{|l|}{ Residence } \\
\hline Rural & 40 & 80.0 \\
\hline Urban & 10 & 20.0 \\
\hline \multicolumn{3}{|l|}{ Education } \\
\hline Low & 33 & 66.0 \\
\hline High & 17 & 34.0 \\
\hline \multicolumn{3}{|l|}{ Occupation } \\
\hline Not working & 30 & 60.0 \\
\hline Working & 20 & 40.0 \\
\hline \multicolumn{3}{|l|}{ Income } \\
\hline Not Enough & 31 & 62.0 \\
\hline Enough & 19 & 38.0 \\
\hline \multicolumn{3}{|l|}{ Marital status } \\
\hline Single & 14 & 28.0 \\
\hline Married & 30 & 60.0 \\
\hline Widow/divorced & 6 & 12.0 \\
\hline \multicolumn{3}{|l|}{ Caregiver of patient } \\
\hline Single parent & 12 & 24.0 \\
\hline Both parents & 4 & 8.0 \\
\hline Brother/sister & 17 & 34.0 \\
\hline Husband/wife & 3 & 6.0 \\
\hline Son/daughter & 14 & 28.0 \\
\hline
\end{tabular}

Table 4 shows that there was statistically significant relationship between total illness perceptions and levels of education post the psycho educational nursing intervention.

Figure 3 shows that there was statistically significant relationship between levels of income and total expressed emotion of the studied group pre the intervention $(p=.018)$.

Table 5 shows that there was no statistically significant relationship either between total illness perception and residence of the studied group post the psycho educational intervention nor, the total expressed emotion and residence.

Table 6 shows that there was statistically significant relationship between level of knowledge and educational level of the studied group post psycho educational intervention. While there is no significant relation between level of knowledge and place of residence.

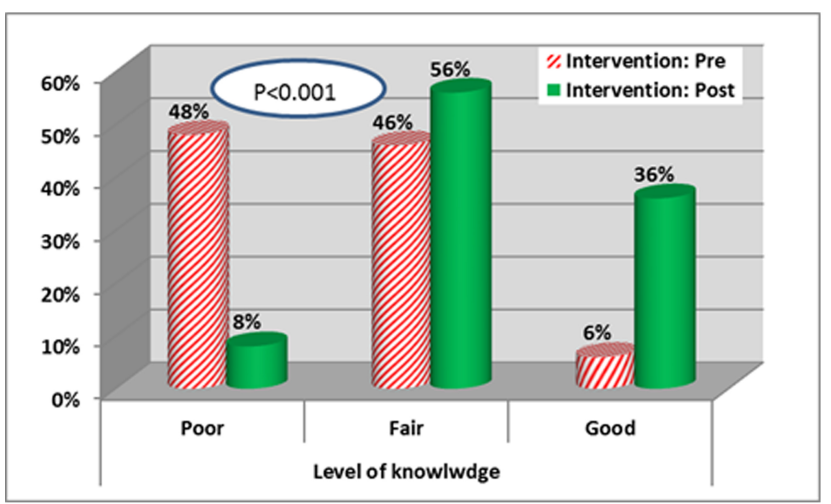

Figure 1. Distribution of the level of knowledge of studied group at pre and post the psycho educational nursing intevention $(\mathrm{N}=50)$

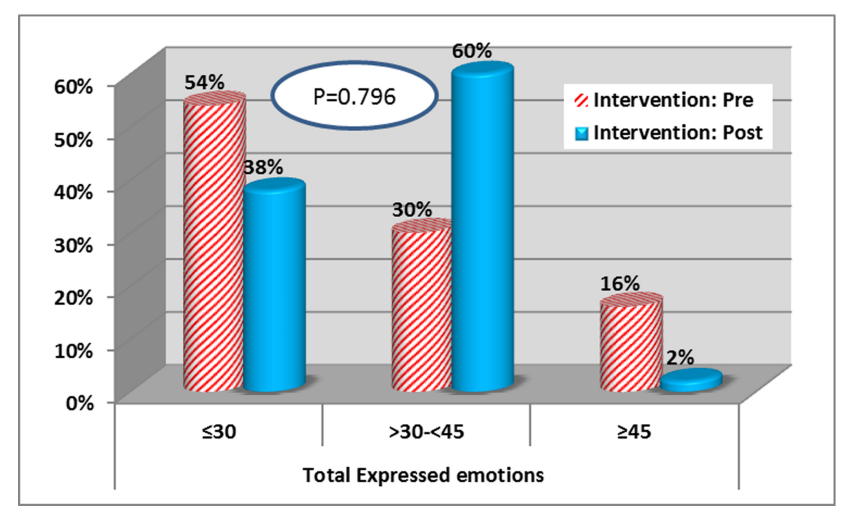

Figure 2. Distribution of the total expressed emotions at pre and post the psycho educational nursing intervention $(\mathrm{N}=$ 50)

\section{Discussion}

This study is based on the recommendations of the "International best-practice guidelines for early psychosis (including the International Early Psychosis Association's and the International Clinical Practice Guidelines for Early Psychosis)", [21] which focused the light on the importance of the provision of psycho education for multifamily groups. Especially families of patient with first episode psychosis.

The current study revealed that the age of caregivers of the studied group ranged from 19 to 70 years old. This result is consistent with Petrakis and Laxton, ${ }^{[22]}$ who mentioned that "the age of the caregivers ranged from 18 to 68 years means that the needs of these caregivers are more diverse". It is important to provide a wide range of informational resources to meet the needs and give adequate amount of time to answer questions of such a group. 
Table 3. Distribution of illness perception at pre and post the psycho educational nursing intervention $(\mathrm{N}=50)$

\begin{tabular}{|c|c|c|c|c|}
\hline \multirow{3}{*}{ Study Variables } & \multicolumn{2}{|l|}{ Intervention } & \multirow{3}{*}{$\begin{array}{l}\text { Wilcoxon } \\
\text { test }\end{array}$} & \multirow{3}{*}{$p$ value } \\
\hline & Pre $(\mathrm{No}=50)$ & Post $(\mathrm{No}=50)$ & & \\
\hline & Mean \pm SD & Mean \pm SD & & \\
\hline \multicolumn{5}{|l|}{ Illness perception subscales: } \\
\hline 1-Ideas about the cause of the disorder & $\begin{array}{l}8.32 \pm 3.34 \\
9(5-11)\end{array}$ & $\begin{array}{l}9.40 \pm 3.09 \\
10(7-12)\end{array}$ & 3.11 & $.002 *$ \\
\hline 2-Pattern and duration of the disorder & $\begin{array}{l}5.94 \pm 2.54 \\
6(4-6)\end{array}$ & $\begin{array}{l}7.04 \pm 2.29 \\
7(5-8)\end{array}$ & 3.89 & $<.001^{*}$ \\
\hline 3-Consequences( Expected effects and outcome of the disorder) & $\begin{array}{l}15.04 \pm 6.54 \\
15(8.75-20.25)\end{array}$ & $\begin{array}{l}16.18 \pm 6.23 \\
16.50(10-23)\end{array}$ & 2.90 & $.004 *$ \\
\hline 4-Usefulness of treatment & $\begin{array}{l}7.18 \pm 2.58 \\
6.50(5-8)\end{array}$ & $\begin{array}{l}8.10 \pm 2.23 \\
8(6-9.25)\end{array}$ & 3.67 & $<.001^{*}$ \\
\hline 5-Control over the disorder & $\begin{array}{l}5.30 \pm 1.72 \\
5(4-6)\end{array}$ & $\begin{array}{l}6.14 \pm 1.89 \\
6(4-8)\end{array}$ & 3.58 & $<.001^{*}$ \\
\hline 6-Self-blame about the disorder & $\begin{array}{l}4.40 \pm 2.04 \\
4(3-5)\end{array}$ & $\begin{array}{l}5.42 \pm 1.88 \\
5(4-7)\end{array}$ & 4.43 & $<.001^{*}$ \\
\hline 7-Illness coherence & $\begin{array}{l}7.36 \pm 2.82 \\
8(5-9)\end{array}$ & $\begin{array}{l}8.22 \pm 2.60 \\
8(6-10)\end{array}$ & 3.38 & $.001^{*}$ \\
\hline 8-Emotional representation & $\begin{array}{l}12.40 \pm 5.18 \\
12(7-16.25)\end{array}$ & $\begin{array}{l}13.60 \pm 4.68 \\
15(8.75-17.25)\end{array}$ & 3.15 & $.002 *$ \\
\hline Total illness perception & $\begin{array}{l}65.90 \pm 23.34 \\
65.50(43-89)\end{array}$ & $\begin{array}{l}74.04 \pm 16.77 \\
73(53-94)\end{array}$ & 4.57 & $<.001^{*}$ \\
\hline
\end{tabular}

Note. Data expressed as Mean \pm SD and Median (IQR); ${ }^{*} p<.05$.

Table 4. Relation between illness perceptionand level of education of studied group at pre and post the psycho-educational nursing intervention $(\mathrm{N}=50)$

\begin{tabular}{|c|c|c|c|c|c|c|}
\hline \multirow{4}{*}{ Study variables } & \multirow{2}{*}{\multicolumn{2}{|c|}{$\begin{array}{l}\text { Pre Intervention } \\
\text { Education }\end{array}$}} & \multirow{4}{*}{$\begin{array}{l}\text { Mann- } \\
\text { Whitney } \\
p \text { value }\end{array}$} & \multirow{2}{*}{\multicolumn{2}{|c|}{$\begin{array}{l}\text { Post Intervention } \\
\text { Education }\end{array}$}} & \multirow{4}{*}{$\begin{array}{l}\text { Mann- } \\
\text { Whitney } \\
p \text { value }\end{array}$} \\
\hline & & & & & & \\
\hline & $\begin{array}{l}\text { Low } \\
(\text { No }=33)\end{array}$ & $\begin{array}{l}\text { High } \\
(\mathrm{No}=17)\end{array}$ & & $\begin{array}{l}\text { Low } \\
(\text { No = 33) }\end{array}$ & $\begin{array}{l}\text { High } \\
(\text { No }=17)\end{array}$ & \\
\hline & Mean \pm SD & Mean \pm SD & & Mean \pm SD & Mean \pm SD & \\
\hline \multicolumn{7}{|l|}{ Illness perception subscales: } \\
\hline 1-Ideas about the cause of the disorder & $7.48 \pm 3.09$ & $9.94 \pm 3.28$ & $\begin{array}{l}2.27 \\
.022 *\end{array}$ & $8.66 \pm 3.02$ & $10.82 \pm 2.78$ & $\begin{array}{l}2.23 \\
.025^{*}\end{array}$ \\
\hline 2-Pattern and duration of the disorder & $5.63 \pm 2.64$ & $6.52 \pm 2.29$ & $\begin{array}{l}1.32 \\
.189\end{array}$ & $6.60 \pm 2.17$ & $7.88 \pm 2.34$ & $\begin{array}{l}1.64 \\
.102\end{array}$ \\
\hline $\begin{array}{l}\text { 3-Consequences( Expected effects and } \\
\text { outcome of the disorder) }\end{array}$ & $13.54 \pm 6.08$ & $17.94 \pm 6.59$ & $\begin{array}{l}2.08 \\
.037 *\end{array}$ & $14.51 \pm 5.85$ & $19.41 \pm 5.81$ & $\begin{array}{l}2.059 \\
.009 *\end{array}$ \\
\hline 4-Usefulness of treatment & $7.0 \pm 2.62$ & $7.52 \pm 2.55$ & $\begin{array}{l}0.92 \\
0.360\end{array}$ & $8.0 \pm 2.23$ & $8.29 \pm 2.28$ & $\begin{array}{l}0.24 \\
.810\end{array}$ \\
\hline 5-Control over the disorder & $5.06 \pm 1.56$ & $5.76 \pm 1.98$ & $\begin{array}{l}1.08 \\
.282\end{array}$ & $6.18 \pm 2.06$ & $6.05 \pm 1.56$ & $\begin{array}{l}0.08 \\
.938\end{array}$ \\
\hline 6-Self-blame about the disorder & $4.12 \pm 2.04$ & $4.94 \pm 1.98$ & $\begin{array}{l}1.55 \\
.121\end{array}$ & $5.18 \pm 1.94$ & $5.88 \pm 1.72$ & $\begin{array}{l}1.22 \\
.225\end{array}$ \\
\hline 7-Illness coherence & $7.0 \pm 2.83$ & $8.05 \pm 2.74$ & $\begin{array}{l}1.26 \\
.212\end{array}$ & $7.78 \pm 2.45$ & $9.05 \pm 2.74$ & $\begin{array}{l}1.61 \\
.108\end{array}$ \\
\hline 8-Emotional representation & $11.75 \pm 5.20$ & $13.64 \pm 5.04$ & $\begin{array}{l}1.34 \\
.181\end{array}$ & $13.03 \pm 4.80$ & $14.70 \pm 4.35$ & $\begin{array}{l}1.44 \\
.153\end{array}$ \\
\hline Total illness perceptions & $61.69 \pm 22.84$ & $74.05 \pm 22.76$ & $\begin{array}{l}1.84 \\
.066\end{array}$ & $69.93 \pm 19.32$ & $82.0 \pm 18.67$ & $\begin{array}{l}2.26 \\
.023 *\end{array}$ \\
\hline
\end{tabular}




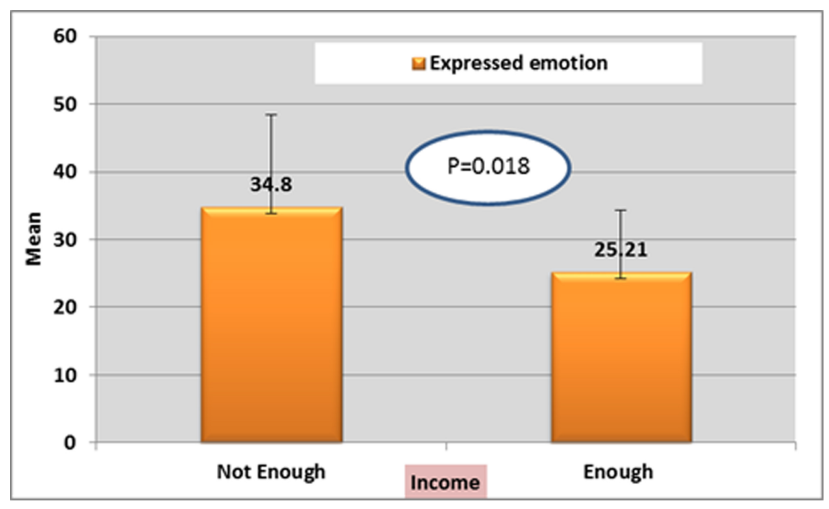

Figure 3. Relation between total expressed emotions and income of studied group at pre the psycho educational nursing intervention $(\mathrm{N}=50)$

Most of the caregivers of the studied group were from rural areas and had low education (rural areas in Egypt have different myths about mental illness, moreover being low educated make the matter of dealing with mental illness more difficult), which make the need for psych educational nurs- ing intervention necessary to improve the family knowledge about psychosis and to be able to support the patients during their different stages of illness.

Regarding to the level of knowledge of caregivers of the patients with first episode psychosis, the result of present study showed that the level of caregivers knowledge has been improved after the completion of the psycho educational nursing intervention. This could be indicated that the program content and session was within the interest and needs of the participants. This result is consistent with the findings of McWilliams et al., ${ }^{[23]}$ whose study showed that "Caregivers knowledge about psychosis and medication treatment improved during a psycho-educational intervention designed specifically for first episode psychosis".

In addition to the previous findings, Worakul et al. ${ }^{[24]}$ who studied the effects of psycho-educational program on knowledge and attitude upon schizophrenia of schizophrenic patients' caregivers the study found that the scores of knowledge and attitude of caregivers, before and after the program were statistically different.

Table 5. Relation between illness perception, total expressed emotions and place of residence of studied group at pre and post the psycho educational nursing intervention $(\mathrm{N}=50)$

\begin{tabular}{|c|c|c|c|c|c|c|}
\hline \multirow{4}{*}{ Study variables } & \multirow{2}{*}{\multicolumn{2}{|c|}{$\begin{array}{l}\text { Pre Intervention } \\
\text { Place of Residence }\end{array}$}} & \multirow{4}{*}{$\begin{array}{l}\text { Mann- } \\
\text { Whitney } \\
p \text { value }\end{array}$} & \multirow{2}{*}{\multicolumn{2}{|c|}{$\begin{array}{l}\text { Post Intervention } \\
\text { Place of Residence }\end{array}$}} & \multirow{4}{*}{$\begin{array}{l}\text { Mann- } \\
\text { Whitney } \\
p \text { value }\end{array}$} \\
\hline & & & & & & \\
\hline & $\begin{array}{l}\text { Rural } \\
\text { No }=40\end{array}$ & $\begin{array}{l}\text { Urban } \\
\text { No }=10\end{array}$ & & $\begin{array}{l}\text { Rural } \\
\text { No }=40\end{array}$ & $\begin{array}{l}\text { Urban } \\
\text { No }=10\end{array}$ & \\
\hline & Mean \pm SD & Mean \pm SD & & Mean \pm SD & Mean \pm SD & \\
\hline \multicolumn{7}{|l|}{ Illness perception subscales: } \\
\hline 1-Ideas about the cause of the disorder & $8.52 \pm 3.49$ & $7.50 \pm 2.63$ & $\begin{array}{l}0.91 \\
.369\end{array}$ & $9.27 \pm 3.35$ & $9.90 \pm 1.72$ & $\begin{array}{l}0.51 \\
.527\end{array}$ \\
\hline 2-Pattern and duration of the disorder & $5.95 \pm 2.58$ & $5.90 \pm 2.51$ & $\begin{array}{l}0.98 \\
.987\end{array}$ & $6.77 \pm 2.11$ & $8.10 \pm 2.76$ & $\begin{array}{l}0.23 \\
.241\end{array}$ \\
\hline $\begin{array}{l}\text { 3-Consequences (Expected effects } \\
\text { and outcome of the disorder) }\end{array}$ & $15.02 \pm 6.65$ & $15.10 \pm 6.45$ & $\begin{array}{l}0.96 \\
.967\end{array}$ & $15.72 \pm 6.28$ & $18.0 \pm 6.01$ & $\begin{array}{l}0.29 \\
.304\end{array}$ \\
\hline 4-Usefulness of treatment & $7.30 \pm 2.52$ & $6.70 \pm 2.90$ & $\begin{array}{l}0.45 \\
.463\end{array}$ & $7.90 \pm 2.20$ & $8.90 \pm 2.28$ & $\begin{array}{l}0.21 \\
.220\end{array}$ \\
\hline 5-Control over the disorder & $5.25 \pm 1.61$ & $5.50 \pm 2.22$ & $\begin{array}{l}0.71 \\
.728\end{array}$ & $6.0 \pm 1.90$ & $6.70 \pm 1.82$ & $\begin{array}{l}0.23 \\
.243\end{array}$ \\
\hline 6-Self-blame about the disorder & $4.37 \pm 1.89$ & $4.50 \pm 2.67$ & $\begin{array}{l}0.97 \\
.978\end{array}$ & $5.17 \pm 1.78$ & $6.40 \pm 2.06$ & $\begin{array}{l}0.09 \\
.094\end{array}$ \\
\hline 7-Illness coherence & $7.50 \pm 2.94$ & $6.80 \pm 2.34$ & $\begin{array}{l}0.51 \\
.526\end{array}$ & $7.92 \pm 2.61$ & $9.40 \pm 2.31$ & $\begin{array}{l}0.11 \\
.116\end{array}$ \\
\hline 8-Emotional representation & $12.45 \pm 5.23$ & $12.20 \pm 5.22$ & $\begin{array}{l}0.96 \\
.967\end{array}$ & $13.25 \pm 4.91$ & $15.0 \pm 3.43$ & $\begin{array}{l}0.28 \\
.297\end{array}$ \\
\hline Total illness perception & $66.32 \pm 23.28$ & $64.20 \pm 24.77$ & $\begin{array}{l}0.86 \\
.872\end{array}$ & $71.92 \pm 20.06$ & $82.50 \pm 18.84$ & $\begin{array}{l}0.10 \\
.109\end{array}$ \\
\hline Total expressed emotion & $30.05 \pm 12.19$ & $35.60 \pm 15.34$ & $\begin{array}{l}1.20 \\
.236\end{array}$ & $32.85 \pm 7.45$ & $33.90 \pm 6.74$ & $\begin{array}{l}0.49 \\
.435\end{array}$ \\
\hline
\end{tabular}


Table 6. Relation between level of knowledge, place of residence and level of education pre and post the psycho educational nursing intervention $(\mathrm{N}=50)$

\begin{tabular}{|c|c|c|c|c|c|c|c|c|}
\hline \multirow{4}{*}{ Study variables } & \multirow{2}{*}{\multicolumn{3}{|c|}{$\begin{array}{l}\text { Pre Intervention } \\
\text { Level of Knowledge }\end{array}$}} & \multirow{4}{*}{$\begin{array}{l}\chi^{2} \\
p \text { value }\end{array}$} & \multirow{2}{*}{\multicolumn{3}{|c|}{$\begin{array}{l}\text { Post Intervention } \\
\text { Level of Knowledge }\end{array}$}} & \multirow{4}{*}{$\begin{array}{l}\chi^{2} \\
p \text { value }\end{array}$} \\
\hline & & & & & & & & \\
\hline & $\begin{array}{l}\text { Poor } \\
(\mathrm{No}=\mathbf{3 1})\end{array}$ & $\begin{array}{l}\text { Fair } \\
(\mathrm{No}=16)\end{array}$ & $\begin{array}{l}\text { Good } \\
(\text { No }=3)\end{array}$ & & $\begin{array}{l}\text { Poor } \\
(\mathrm{No}=24)\end{array}$ & $\begin{array}{l}\text { Fair } \\
(\mathrm{No}=23)\end{array}$ & $\begin{array}{l}\text { Good } \\
(\text { No }=3)\end{array}$ & \\
\hline & $\%$ & $\%$ & $\%$ & & $\%$ & $\%$ & $\%$ & \\
\hline \multicolumn{9}{|l|}{ Education } \\
\hline Low & 63.6 & 30.3 & 6.10 & 0.13 & 9.1 & 60.6 & 30.3 & 9.84 \\
\hline High & 58.8 & 35.3 & 5.90 & .937 & 5.9 & 17.6 & 76.5 & $.007 *$ \\
\hline \multicolumn{9}{|l|}{ Residence } \\
\hline Rural & 50.0 & 45.0 & 5.0 & 0.54 & 10.0 & 57.5 & 32.5 & 1.76 \\
\hline Urban & 40.0 & 50.0 & 10.0 & .762 & 0.0 & 50.0 & 50.0 & .415 \\
\hline
\end{tabular}

Concerning to the caregivers perception of illness, results showed that there was a statistically significant difference between the caregivers' perception of illness before and after the psych educational nursing intervention. This indicate the effectiveness of the program which means that the psycho educational program has a vital role in improving the caregivers perception of illness through increasing their knowledge about mental illness, answering their questions and correcting myths about mental illness and psychiatric treatment. This result is consistent with soliman et al. ${ }^{[25]}$ who found that psycho education was effective both in improving patients, medical condition and improving caregivers perception of illness resulting in reducing the family burden. Also supported with the findings of Bulut et al., ${ }^{[26]}$ as they mentioned that psycho education leading to improve caregivers perception of illness.

As a core point in the study the expressed emotion of the studied caregivers before the program was high. The psycho educational nursing intervention did not reduce the level of expressed emotion of care givers to a degree that is considered statistically significant. This could be explained that the data was collected during the first episode of psychosis and the patients were acutely symptomatic. These symptoms are disturbing to the patient and the family, which contribute to the elevated level of expressed emotions. This result is matched with the preexisting literature review, Mertinez et al. ${ }^{[13]}$ found that expressed emotion (criticism and EOI) were strongly high especially in the early stage of psychosis. In the same line Sadath et al. ${ }^{[4]}$ found that nearly half of the caregivers of his sample showed high level of expressed emotion.

Results showed that there was a statistically significant difference between levels of income of the studied group regarding to the total expressed emotion. This result is consistent with

Published by Sciedu Press sadath et al. ${ }^{[4]}$ who found that there was inverse correlation between monthly income and level of expressed emotion as many caregivers of psychosis were unable to afford their relatives' treatment expenses due to financial difficulties, which in turn increase level of expressed emotions. This relation explain the previous findings (level of expressed emotion did not improve to that significant level), because financial factors play a significant role in affecting on level of expressed emotion, and that factor cannot be controlled during the psycho educational intervention.

Regarding to the socio demographic characteristics of the studied participants which include residence and its relationship with expressed emotion, level of knowledge about mental illness and illness perception, results showed that there was no statistical relationship between the study participants' residence and their expressed emotion, level of knowledge and illness perception. This may be due to the nature of Egypt as a developing country, there is a general literacy about mental illness and that people had different views about mental illness, especially its causal and treatment option, which make the experience of caring for mentally ill patient is extremely strange and vague duty. And that regardless of the residence of the caregivers negative perception and poor knowledge about mental illness were the common theme of most of our study participants.

These results are congruent with Mc Williams et al. ${ }^{[23]}$ who found that gender and socio demographic characteristics did not make any difference in the improvement of the psycho educational program.

As regards to the level of education of the studied participants and its relationship with level of knowledge and illness perception, results showed that there were statistical significant differences among the level of education, level of knowledge and illness perception of the studied participants post the 
psycho educational intervention. This means that the level of education has a significant role in improving the level of knowledge and illness perception of the studied participants.

This result is consistent with Benti et al., ${ }^{[27]}$ who studied "Community Perception towards Mental Illness among Residents of Gimbi Town, Western Ethiopia" the results found that the ducational level is one of the socio demographic characteristics significantly affecting perception of mental illness in this study. About $90 \%$ of respondents who have no formal education more likely to have poor perception when compared with degree holders and above. As low educated caregivers tended to correlate mental illnesses to supernatural power, spiritual causes or evil forces. This may be explained in the higher stigma of mental illness in developing countries leads to denial to accept the existence of mental illness and the belief of spiritual causes.

The overall findings of this study showed that the psychoeducational intervention has a positive effect on the caregivers' perception of illness and levels of knowledge about mental illness. This indicates that the program content was within the needs and interests of the participant. These findings are consistent with Sin et al. ${ }^{[28]} \&$ YÜKSEL ${ }^{[29]}$ who found that "a one day intensive psycho-educational workshop included with audiovisual components, written material package about schizophrenia and an interactive discussion part has a positive effect on perception of illness, recognizing about care giving, expressed emotion levels and knowledge about schizophrenia".

\section{Conclusion}

The current study concluded that

- Psycho educational nursing intervention was effective in improving caregivers' level of knowledge about mental illness and illness perception.

- Based on improving the level of knowledge and perception of illness of care givers of patients with first episode psychosis, there was improvement in the level of expressed emotions but doesn't research a significant level.

\section{Recommendation}

- The study recommends to urgently utilizing psychoeducational nursing intervention for all caregivers of patients with first episode psychosis in all psychiatric hospitals.

- Enhance the role of community psycho-educational groups and public mental health service to provide support and required knowledge about management and care of patient with first episode psychosis.

- Increase the awareness of community about management of psychiatric illness through media to decrease the stigma of mental illness which lead to improve the general health of patients and their families.

\section{CONFLicts OF InTEREST Disclosure}

The authors declare that there is no conflict of interest.

\section{REFERENCES}

[1] American Psychiatric Association. Diagnostic and statistical manual of mental disorders. Washington. D.C: American Psychiatric Association. 2013; 125. https://doi.org/10.1176/appi . books . 978 0890425596

[2] Vinberg M, Miskowiak K, Kessing L. Risk markers for affective disorder, a seven-years follow-up study of a twin cohort at low and high risk for affective disorder. J Psychiatr Res. 2013; 475: 565-71. PMid:23399485 https://doi.org/10.1016/j.jpsychires.2 013.01 .013

[3] Koutra K, Triliva S, Roumeliotaki T, et al. Family functioning in families of first-episode psychosis patients as compared to chronic mentally ill patients and healthy controls. Psychiatry Research. 2016; 219: 486-496. PMid:25024058 https://doi.org/10.1016/j. psychres.2014.06.045

[4] Sadath A, Muralidar D, Varambally S, et al. Family Intervention in First-Episode Psychosis: A Qualitative Systematic Review. SAGE Open; 2015; 1-11.

[5] Petrakis M, Oxley J, Bloom H. Carer psycho education in first episode psychosis: Evaluation outcomes from a structured group program. International Journal of Social Psychiatry. 2013; 59(4): 391-397.
PMid:22433244 https://doi.org/10.1177/00207640124384 76

[6] Chien W, Chan W. The effectiveness of mutual support group intervention for Chinese families of people with schizophrenia: a randomized controlled trial with 24-month follow-up. Int. J. Nurs. Stud. 2013; 50(10): 1326-1340. https://doi.org/10.1016/j.ijnu rstu.2013.01.004

[7] Roseliza-Murni A, Oei T, Fatimah Y, et al. Schizophrenia relapse in Kuala Lumpur, Malaysia: do relatives' expressed emotion and personality traits matter? Compr Psychiatry. 2014; 55: 188-198. https://doi.org/10.1016/j.comppsych.2012.12.026

[8] Hayes L, Hawthorne G, Farhall J, et al. Quality of life and social isolation among caregivers of adults with schizophrenia: Policy and outcomes. Community Mental Health Journal. 2015; 51: 591-597. PMid:25690154 https://doi.org/10.1007/s10597-015-984 8-6

[9] Hernandez M, Barrio C. Perceptions of subjective burden among Latino families caring for a loved one with schizophrenia. Community Mental Health Journal. 2015; 1-10.

[10] Foster A, Dickerson J, Melbourn A, et al. The development and implementation of the structured training program for caregivers of inpatients after stroke (TRACS) intervention. The London Stroke 
Carers Training Course. Clinical Rehabilitation. 2015; 29(3): 211220. PMid:25057000 https://doi.org/10.1177/0269215514 543334

[11] Valeberg B, Kolstad E, Smastuen C, et al. The PRO-SELF pain control program improves family caregivers' knowledge of cancer pain management. Cancer Nurs. 2013; 36(6): 429-435. PMid:23154516 https://doi.org/10.1097/NCC.0b013e3182747bcf

[12] International Early Psychosis Association Writing Group. International clinical practice guidelines for early psychosis. The British Journal of Psychiatry. 2005; 187(48): 120-124. https://doi.org/ 10.1192/bjp.187.48.s120

[13] Martínez T, Pradas C, Kwapil T, et al. Relatives' expressed emotion, distress and attributions in clinical high-risk and recent onset of psychosis. Psychiatry Research. 2017; 247: 323-329. PMid:27951481 https://doi.org/10.1016/j.psychres .2016.11.048

[14] Kreyenbuhl J, Buchanan R, Dickerson F, et al. The schizophrenia patient outcomes research team (PORT): Updated treatment recommendations. Schizophrenia Bulletin. 2010; 36(1): 94-103. PMid:19955388 https://doi.org/10.1093/schbul/sbp130

[15] Xia J, Merinder L, Belgamwar M. Psycho education for schizophrenia. In Cochrane Database Systematic Reviews. Cochrane Library Oxford; 2011.

[16] Xia J, Zhao S, Jayaram M. Psycho education (brief) for people with serious mental illness. In: Cochrane Database Systematic Reviews. 2013.

[17] Birchwood M, Smith J, Cochrane R. Specific and non-specific effects of educational intervention for families living with schizophrenia. A comparison of three methods. Br J Psychiatry. 1992; 160: 806-14. https://doi.org/10.1192/bjp.160.6.806

[18] Wiedemann G, Rayki O, Feinstein E, et al.The Family Questionnaire: development and validation of anew self-report scale for assessing expressed emotion. Psychiatry Research. 2002; 109(3): 265-279. https://doi.org/10.1016/S0165-1781(02)00023-9

[19] Koutra K, Economou M, Triliva S, et al. Cross-cultural adaptation and validation of the Greek version of the Family Questionnaire for assessing expressed emotion. Comprehensive Psychiatry. 2014.

[20] Lobban f, Barrowclough C, Jones S. Assessing cognitive representation of mental health problems: The Illness Perception Questionnaire for Schizophrenia. British Journal of Clinical Psychology. 2005; 44: 147-162. PMid:16004651 https://doi.org/10.1348/0144 $66504 \mathrm{X} 19497$

[21] International Early Psychosis Association Writing Group, International Clinical Practice Guidelines. Br J Psych. 2005; 187(Suppl. 48): 120-124. https://doi.org/10.1192/bjp.187.48.s120

[22] Petrakis M, Laxton S. Intervening Early with Family Members during First-Episode Psychosis: An Evaluation of Mental Health Nursing Psycho education within an Inpatient Unit. Archives of Psychiatric Nursing. 2017; 31: 48-54. PMid:28104058 https: //doi.org/10.1016/j.apnu.2016.07.015

[23] McWilliams S, Egan P, Jackson D, et al. Caregiver psycho education for first-episode psychosis. European Psychiatry. 2010; 25: 33-38. PMid:19926257 https://doi.org/10.1016/j. eurpsy .2009 .08 .006

[24] Worakul P1, Thavichachart N, Lueboonthavatchai P. Effects of psycho-educational program on knowledge and attitude upon schizophrenia of schizophrenic patients' caregivers. J Med Assoc Thai. 2007; 90(6): 1199-204.

[25] Soliman E, Mahdy R, Fouad H. Impact of psycho education program on quality of life of schizophrenic patients and their caregivers. Egypt J Psychiatry. 2018; 39: 35-41.

[26] Bulut M, Arslantas H, Ferhan Dereboy I. Effects of psycho education given to caregivers of people with a diagnosis of schizophrenia. Issues Ment Health Nurs. 2016; 37: 800-810. PMid:27696929 https://doi .org/10.1080/01612840.2016.1222039

[27] Benti M, Ebrahim J, Awoke T, et al. Community Perception towards Mental Illness among Residents of Gimbi Town, Western Ethiopia. Psychiatry Journal. 2015.

[28] Sin J, Gillard S, Spain D, et al. Effectiveness of psycho educational interventions for family carers of people with psychosis: A systematic review and meta-analysis. Clinical Psychology Review. 2017; 56: 13-24. PMid:28578249 https://doi .org/10.1016/j . cpr . 2017.05.002

[29] Yuksel M. The effects of brief psycho education program on the perceived expressed emotion levels of outpatient schizophrenic patients and expressed emotion levels and burn out levels of their key relatives. 2008. Available from: http://citeseerx.ist.psu.edu/view doc/download?doi=10.1.1.633.8522\&rep=rep1\&type=pdf 